\title{
PENGEMBANGAN KECERDASAN SPIRITUAL SISWA DI SD ISLAM TOMPOKERSAN LUMAJANG
}

\author{
Lufiana Harnany Utami \\ UIN Sunan Gunung Djati Jl. A.H. Nasution 105 Bandung \\ e-mail: lufianaharnany@gmail.com
}

\begin{abstract}
Spiritual quotient function transforming spiritual values such as honesty, affection, fairness, responsibility, peacefulness, trust, and togetherness. Developing Spiritual quotient aims to make students have full understanding about lesson of Islam and be able to apply it in daily life. Students hoped to be the one who believe in Allah SWT and actualize themselves based on lesson and norm in Islam with Islamic personality and akhlakul karimah. This research uses qualitative approach by having interview with subjects. Result shows that spiritual quotient development is carried through structural and unstructural programs. Structural programs applied in learning activity while unstructural ones done through extracuriculer activites. Methods of development are giving assignment, nurturing, transforming knowledge, having creative activity, making relationship having leadership.
\end{abstract}

Keywords : spiritual quotient, structural programs, unstractural programs

\begin{abstract}
Abstrak
Kecerdasan spiritual berfungsi mentransformasi nilai-nilai spiritual seperti kejujuran, kasih sayang, keadilan, kejujuran, tanggungjawab, kedamaian, kepercayaan dan kebersamaan. Pengembangan kecerdasan spiritual bertujuan agar siswa memiliki pemahaman yang utuh tentang ajaran islam dan dapat mengaplikasikannya dengan benar dalam kehidupan sehari-hari. Siswa juga diharapkan menjadi manusia yang beriman dan bertaqwa kepada Allah SWT serta mampu mengaktualisasikan dirinya sesuai dengan ajaran dan norma agama Islam dengan kepribadian Islami dan berakhlakul karimah. Penelitian ini menggunakan pendekatan kualitatif dengan menggunakan teknik wawancara pada subyek penelitian. Hasil penelitian menunjukkan bahwa pengembangan kecerdasan spiritual dilakukan melalui program yang terstruktur yaitu dalam kegiatan belajar mengajar sehari-hari dan program tidak terstruktur dengan berbagai kegiatan ekstrakurikuler. Adapun metode dilakukan melalui pemberian tugas, pengasuhan, pengetahuan, kegiatan kreatif, persaudaraan dan kepemimpinan.
\end{abstract}

Kata kunci : kecerdasan spiritual, program terstruktur, program tidak terstruktur

\section{PENDAHULUAN}

Pendidikan pada umumnya bertujuan untuk membekali individu dengan nilai dan norma yang akan menjadi panduan dalam bersikap. Mendidik tidak hanya memberikan ilmu pengetahuan dan ketrampilan tetapi juga menanamkan nilai dan norma susila yang luhur dan mulia. Pada dasarnya potensi yang diberikan Allah kepada manusia sangat banyak dengan variasi yang berbeda. Potensi kecerdasan intelektual (Intellectual Quotient, IQ), kecerdasan emosi (Emotional Quotient, EQ) dan kecerdasan spiritual (Spiritual Quotient, SQ) bervariasi kondisinya pada setiap individu.

Menurut Ary Ginanjar Agustian (2001) SQ adalah landasan yang diperlukan untuk memfungsikan IQ dan EQ secara efektif. Dengan IQ yang tinggi orang dapat menjadi ahli dalam bidang intelektual, demikian pula dengan peran EQ yang penting dalam membangun hubungan antar manusia yang efektif. Namun tanpa SQ yang mengajarkan nilai-nilai kebenaran, maka keberhasilan akan menghasilkan sejumlah Hitler atau Fir'aun baru di muka bumi. SQ berfungsi untuk mentransformasi nilai-nilai spiritual atau nilai-nilai agama seperti kejujuran, kasih sayang, keadilan, kejujuran, tanggungjawab, kedamaian, kepercayaan dan kebersamaan.

Salah satu kelebihan manusia sebagai makhluk Allah adalah dianugerahi fitrah (perasaan dan kemampuan) untuk mengenal Allah dan 
melaksanakan ajarannya. Fitrah merupakan dasar yang dapat berkembang arah dan kualitasnya karena sangat tergantung pada proses pendidikan yang diterimanya. Hal ini sebagaimana yang telah dinyatakan oleh Nabi Muhammad SAW bahwa; 'Setiap anak dilahirkan berdasarkan fitrah, hanya karena orangtuaanak itu menjadi Yahudi, Nasrani, atau Majusi. Peran SQ sangat dibutuhkan untuk mengembangkan fitrah yang ada pada manusia agar sesuai dengan ajaran Islam.

Persoalan yang muncul dewasa ini adalah terjadinya krisis spiritualitas pada diri anak dan remaja. Tak jarang kita melihat adanya kriminalitas yang dilakukan anak-anak seperti perampokan, perjudian, tawuran antar sekolah, pembunuhan, kecanduan narkoba dan lainnya. Hal ini disebabkan karena tidak adanya keseimbangan antara nilai-nilai keagamaan pada diri individu dengan perkembangan zaman yang semakin maju. Untuk itu masalah akhlak atau moral memerlukan perhatian khusus sehingga mampu membentengi anak dari hal-hal yang tidak diinginkan.

Selain itu terdapat juga berbagai masalah dalam dunia pendidikan Islam. Siswa secara terus-menerus mempelajari agama Islam dari segala aspek akan tetapi mereka belum secara penuh mengaplikasikannya dalam kehidupan sehari-hari. Selain itu siswa juga kurang mempunyai tanggung jawab terhadap dirinya dan orang lain seperti masih cenderung melakukan sesuatu yang bertentangan dengan ajaran islam.

Mengingat potensi yang dimiliki siswa harus dikembangkan agar mereka mempunyai arahan dan tujuan dalam hidupnya, maka pengembangan SQ bagi siswa sangat diperlukan. Pengembangan SQ dimaksudkan agar siswa memiliki pemahaman yang utuh tentang ajaran islam dan dapat mengaplikasikannya dengan benar dalam kehidupan sehari-hari. Siswa juga diharapkan menjadi manusia yang beriman dan bertaqwa kepada Allah SWT serta mampu mengaktualisasikan dirinya sesuai dengan ajaran dan norma agama Islam dengan kepribadian Islami dan berakhlakul karimah.

Begitu juga dengan SD Islam Tompokersan Lumajang sebagai sekolah yang berciri khas Islam dimana para siswa memerlukan bimbingan dan arahan melalui penanaman keyakinan atas prinsip-prinsip ajaran Islam. Penanaman akan pembiasaan dalam kehidupan sehari-hari sangat diperlukan agar mereka tidak terjerumus di jalan yang salah serta dapat mengontrol diri mereka sendiri dan dapat memberikan makna pada setiap perbuatan yang dilakukannya. Me- ngamati beberapa pemikiran di atas maka penulis mencoba mengamati tentang "Pengembangan Kecerdasan Spiritual Siswa di SD Islam Tompokersan Lumajang."

Penelitian ini bertujuan untuk mengetahui upaya SD Islam Tompokersan Lumajang dalam mengembangkan kecerdasan spiritual siswa. Selain itu juga untuk mengetahui problematika yang dihadapi dalam pengembangan kecerdasan spiritual siswa di SD Islam Tompokersan Lumajang.

Kegunaan penelitian ini adalah menambah pengetahuan dan mengembangkan wawasan upaya pengembangan kecerdasan spiritual siswa. Memberikan sumbangan pemikiran bagi pengembangan ilmu pengetahuan dan lembaga pendidikan lainnya serta memberikan gagasan bagi pembaca dan masyarakat pada umumnya tentang penerapan pengembangan kecerdasan spiritual.

Ngermanto (2005) menganggap kecerdasan spiritual adalah dimensi non material yang digunakan untuk "berhubungan" dengan Tuhan yang tidak dibatasi oleh faktor keturunan, lingkungan atau materi lainnya. Sementara Zohar dan Marshall (2002) mendefinisikan kecerdasan spiritual sebagai kecerdasan untuk menghadapi dan memecahkan persoalan makna dan nilai. Kecerdasan ini menempatkan perilaku dalam konteks makna yang lebih luas dan merupakan fondasi untuk memfungsikan IQ dan EQ secara efektif.

Sukidi (2004) menggambarkan kecerdasan spiritual sebagai cahaya yang membangunkan orang dalam segala situasi dan menghidupkan kebenaran yang paling dalam. Agustian (2001) menambahkan bahwa kecerdasan spiritual merupakan kecerdasan jiwa yang dapat membantu seseorang membangun dirinya secara utuh yang tidak bergantung pada budaya dan nilai. Kecerdasan spiritual adalah kesadaran dalam diri yang membuat manusia mampu membedakan yang salah dan yang benar serta bijaksana. Lebih dalam Nafis (2006) menegaskan bahwa kesadaran spiritual bukanlah doktrin agama yang mengajak umat manusia untuk 'cerdas' dalam memilih atau memeluk salah satu agama yang dianggap benar. Kecerdasan spiritual lebih merupakan sebuah konsep yang berhubungan dengan bagaimana seseorang 'cerdas' dalam mengelola dan mendayagunakan makna-makna, nilai-nilai, dan kualitas-kualitas kehidupan spiritualnya.

Kehidupan spiritual meliputi hastrat untuk hidup bermakna yang memotivasi kehidupan manusia untuk senantiasa mencari makna hidup 
dan mendambakan hidup bermakna (Mujib dan Mudzakir, 2002). Makna yang paling tinggi dan paling bermakna, dimana manusia akan merasa bahagia justru terletak pada aspek spiritualitasnya. Zohar dan Marshal (2002) menekankan masalah makna dan nilai sebagai kunci untuk memahami SQ. Secara definitif, Ngermanto (2002) mengatakan bahwa: "Makna bersifat substansial dan berdimensi spiritual. Makna adalah penentu identitas sesuatu yang paling signifikan. Manusia yang memiliki kualitas kecerdasan spiritual yang tinggi menemukan makna yang terdalam dari segala sisi kehidupan. Baik karunia maupun ujian dapat difahami sebagai wahana pendewasaan spiritual bagi manusia.

Zohar dan Marshal (2002) menegaskan bahwa SQ adalah fondasi yang diperlukan untuk memfungsikan IQ dan EQ secara efektif. SQ dapat dikatakan sebagai kecerdasan tertinggi manusia. Hal ini secara langsung atau tidak langsung berhubungan dengan kemampuan manusia mentrasendensikan diri. Transendensi merupakan kualitas tertinggi dari kehidupan spiritualyang membawa manusia "mengatasi" (beyond)-mengatasi masa kini, mengatasi rasa suka dan rasa duka, bahkan mengatasi diri kita pada saat ini. Ia membawa manusia melampaui batas-batas pengetahuan dan pengalaman serta menempatkan pengetahuan dan pengalaman dalam konteks yang lebih luas.

Mujid dan Mudzakir (2002) menyimpulkan kecerdasan intelektual (intellectual Quotient, $I Q$ ) adalah kecerdasan yang berhubungan dengan proses berfikirdengan menggunakan logika. Melalui tes IQ (intellectual Quotient), tingkat kecerdasan intelektual seorang dapat dibandingkan dengan orang lain. Suharsono (2005) menggambarkan IQ adalah cermin kemampuan seseorang dalam memahami dunia luar. Mestinya semakin tinggi IQ seseorang akan semakin dekatlah ia kepada Pencipta-Nya Allah SWT karena yang disebut sebagai dunia luar itu adalah kata lain dari ayat-ayat Allah.

Adapun kecerdasan emosional, baru dikenal secara luas pada pertengahan tahun 90-an dengan diterbitkannya buku Daniel Goleman "Emotional Intellegence" pada tahun 1995 setelah ia melakukan penelitian EQ lebih dari 10 tahun. Goleman (1995) menjelaskan bahwa kecerdasan emosi (Emotional Intellegence) adalah kemampuan untuk mengetahui perasaan kita sendiri dan perasaan orang lain, memotivasi diri sendiri dan mengelola dengan baik hubungan dengan orang lain.EQ juga mengajarkan dan menanamkan rasa empati, cinta, inovasi, dan kemampuan untuk menanggapi kesedihan atau kegembiraan secara cepat.

Menurut Goleman (1995), emotional competent (kecakapan emosi) memiliki 5 wilayah kerja yaitu self awareness (kesadaran diri), self regulation (pengaturan diri), motivation (motivasi), empathy (empati) dan social-skills (ketrampilan sosial). Menurut Suharsono (2005) kecerdasan emosional tidak hanya berfungsi untuk mengendalikan diri, tetapi lebih dari itu juga mencerminkan kemampuan dalam "mengelola" ide, konsep, karya atau produk, sehingga hal itu menjadi minat bagi orang banyak. Ada banyak keuntungan bila seseorang tidak terjerumus kedalam tindakan-tindakan bodoh, yang merugikan dirinya sendiri maupun orang lain. Kedua kecerdasan emosional bisa diimplementasikan sebagai cara yang sangat baik untuk memasarkan atau membesarkan ide, konsep, atau bahkan sebuah produk. Ketiga, kecerdasan emosional adalah modal penting bagi seseorang untuk mengembangkan bakat kepemimpinan, dalam bidang apapun juga Itulah maka EQ justru dikatakan lebih besar dan lebih menentukan daripada IQ dalam meraih kesuksesan hidup manusia.

Masih menurut Suharsono (2005) lain halnya jika kita membicarakan kecerdasan spiritual bentuk kecerdasan yang ketiga. Berbeda dengan IQ, yang memandang dan menginterpretasikan sesuatu dalam kategori kuantitatif (data dan fakta) serta gejala (fenomena). Kecerdasan spiritual memandang dan menginterpretasikan sesuatu tak hanya bersifat kualitatif dan fenomenal, tetapi melangkah lebih jauh dan mendalam, yakni pada dataran epistemic dan ontologis (substansial). Kecerdasan spiritual juga berbeda dengan kecerdasan emosional, dalam melihat dan menyadari diri. Pada kecerdasan emosional manusia dilihat dan dianalisis dalam batas-batas psikologis dan sosial, sementara pada kecerdasan spiritual, manusia diinterpretasi dan dipandang eksistensinya sampai dataran noumenal (fitriyah) dan universal.

Kecerdasan intelektual berada di wilayah otak, kecerdasan emosional mengambil tempat di sekitar emosi sedangkan kecerdasan spiritual mengambil tempat diseputar jiwa. Jika IQ berperan memberi solusi intelektual, EQ merupakan jalan membangun relasi, sementara SQ mempertanyakan apakah makna, tujuan dan filsafat hidup 
seseorang. SQ inilah yang digunakan untuk seseorang untuk berhubungan dengan Tuhan.

Menurut Zohar dan Marshal (2002) SQ berfungsi untuk mengembangkan diri kita secara utuh dan membantu kita menjalani hidup pada tingkatan makna yang lebih dalam. Kecerdasan spiritual itu membuat kita mampu menyadari siapa kita sesungguhnya dan bagaimana kita memberi makna terhadap hidup kita.SQ memungkinkan kita untuk menyatukan hal-hal yang bersifat intrapersonal dan interpersonal, serta menjembatani kesenjangan antara diri sendiri dengan orang lain. Satiadarma dan Waruwu (2003) menjelaskan bahwa kita menggunakan kecerdasan spiritual pada saat kita berhadapan dengan masalah eksistensial seperti saat merasa terpuruk, terjebak oleh kebiasaan, kekhawatiran, dan masalah masa lalu kita sebagai akibat penyakit dan kesedihan. Agar kita memiliki kecerdasan spiritual secara utuh, terkadang kita harus merasakan derita, sakit, kehilangan, putus asa, dan kesusahan. Ketika manusia pasrah secara spiritualSQ memberikan ketenangan tertinggi.

Zohar dan Marshal (2002) memberikan gambaran ciri-ciri orang yang mempunyai SQ tinggi seperti memiliki kemampuan bersikap fleksibel (adaptif secara spontan dan aktif), tingkat kesadaran diri yang tinggi, kemampuan untuk menghadapi dan memanfaatkan penderitaan serta mempunyai kualitas hidup yang diilhami oleh visi dan nilai-nilai. Selain itu enggan untuk menyebabkan kerugian, cenderung melihat keterkaitan antara berbagai hal (berpandangan 'holistik"), bertanya "mengapa" atau "bagaimana jika" untuk mencari jawaban yang dasar.

Sementara Ngermanto (2005) juga menggambarkan beberapa ciri orang yang ber-SQ tinggi, diantaranya adalah memiliki prinsip dan visi yang merupakan kebenaran yang hakiki dan fundamental. Beberapa contoh prinsip seperti prinsip kebenaran, keadilan, dan kebaikan. Kedua memiliki semangat kesatuan dalam keberagaman artinya mampu melihat bahwa manusia yang satu dengan yang lainnya adalah berbeda akan tetapi ketunggalan dalam keberagamaan adalah prinsip utama. Selanjutnya adalah seseorang yang memiliki SQ tinggi dapat menemukan makna terdalam dari segala sisi kehidupan. Individu yang memiliki SQ tinggi mampu mentransformasikan kesulitan menjadi satu medan penyempurnaan dan pendidikan spiritual yang bermakna.
Menurut Sukidi (2004) kecerdasan spiritual membimbing kita untuk mendidik hati menjadi benar serta berbudi pekerti yang baik. Pada dasarnya manusia dilahirkan dalam keadaan suci, kesucian manusia itu bisa dikenal dengan istilah fitrah. Dengan fitrah tersebut menjadikan manusia mempunyai sifat dasar kesucian yang kemudian harus dinyatakan dengan sikap yang suci pula kepada sesamanya.

Agustian (2001) menambahkan pada dasarnya manusia mempunyai prinsip dasar kesadaran fitrah (awareness). Jalan fitrah adalah suatu tindakan yang dibimbing oleh suara hati. Hal ini sesuai dengan firman Allah dan surat Asy-Syams ayat 8-10 yang artinya: "Maka Sesungguhnya beruntunglah orang yang mensucikan jiwa itu. Dan sesungguhnya merugilah orang yang mengotorinya".(Depag, 1996). Seseorang yang ingin cerdas meraih hidup secara spiritual harus melakukan berbagai perbuatan positif berdasarkan pengetahuan dan pengajaran. Kecerdasan spiritual juga mendidik hati kita kedalam budi pekerti yang baik dan moral yang beradab.

Modernisasi menjadikan manusia banyak yang melepaskan diri dari keterkaitannya dengan Tuhan yang selanjutnya membangun tatanan manusia yang semata-mata berpusat pada manusia. Manusia menjadi tuan atas nasibnya sendiri yang mengakibatkan mereka terputus dengan nilai-nilai spiritual sehingga mereka tidak dapat menjawab persoalan-persoalan hidup itu sendiri. Modernisasi akhirnya dirasakan membawa kehampaan dan ketidabermaknaan hidup yang menyebabkan munculnya penyakit spiritual. Adapun akar dari penyakit spiritual adalah kehilangan visi keilahian dan kehampaan spiritual.

Mengapa diri kita mengalami krisis spiritual. Menurut Sukidi (2004) kita tidak pernah mengisi ruang spiritual itu dengan hal-hal yang baik dalam kehidupan kita dan justru sebaliknya kita terbiasa mengisinya dengan hal-hal yang buruk. Hal itu dengan sendirinya menjadikan hidup kita menjadi jauh dari Tuhan dan kita tidak menemukan makna dari hidup kita. Fenomena di atas berakibat bukannya semakin mendekati kebahagiaan hidup akan tetapi sebaliknya mereka kian dihinggapi rasa cemas. Manusia modern terjangkit penyakit keterasingan diri (aliensi) baik dari diri sendiri, lingkungan sosial, maupun teraliensi dari Tuhannya.

Zohar dan Marshal (2002) menambahkan bahwa kondisi Psikologis di atas merupakan bentuk dari keterputusan diri, baik dari sendiri, dari orang lain di sekelilingnya, dan bahkan dari 
Tuhannya. Masyarakat modern saat ini sedang berada di wilayah pinggiran eksistensinya sendiri, bergerak menjauh dari pusat (Tuhan). Mereka sudah merasa cukup dengan perangkat ilmu dan teknologi, sementara pemikiran dan paham keagamaan yang bersumber pada ajaran wahyu dan sunah Rasul semakin ditinggalkan.

Masyarakat telah memasuki paham sekulerisme. Sukelerisme dapat dipahami sebagai pemisahan antara institusi agama sebagai sumber tatanan nilai dan norma dengan berbagai perilaku manusia dalam memenuhi kebutuhannya yang bersifat materi. Proses sekulerisme ini menyebabkan manusia mengalami kehilangan kontrol diri (Self control) sehingga mudah dihinggapi berbagai penyakit rohaniyah seperti ia lupa siapa dirinya, dan untuk apa tujuan hidup ini.

Kehampaan spiritual terjadi karena manusia terlalu sibuk dan bahkan lebih mengutamakan kepentingan dunia yang mampu memenuhi kebutuhan pokok manusia, apalagi dengan didukung adanya kemajuan teknologi yang semakin canggih (Sukidi, 2004). Kondisi manusia sekarang ini, karena mengabaikan kebutuhannya yang paling mendasar, yang bersifat spiritual, maka mereka tidak bisa menemukan ketentraman batin. Mereka kalut dan kehilangan kendali dalam menghadapi kehidupan karena jiwa dan batin mereka sibuk mencari, tapi tidak tahu apa yang mereka cari sehingga inilah yang menyebabkan kehampaan spiritual.

Menurut Zohar dan Marshall (2002) pengembangan kecerdasan spiritual merupakan sarana untuk berhubungan dengan Tuhan karena di dalamnya terdapat perbuatan-perbuatan sebagai pendakian transcendental sehingga manusia akan merasa lebih dekat dengan Tuhan. Suharsono (2005) memberikan elaborasi yang sangat menarik berkenaan dengan kecerdasan spiritual. Menurutnya tahapan intelegensi manusia berlangsung melalui jalur Iqro', yakni 5 ayat pertama surat Al-Alaq:" yang artinya :

Bacalah dengan menyebut nama TuhanMu yang menciptakan. Dia telah menciptakan manusia dari segumpal darah. Bacalah! Dan Tuhanmulah Yang paling Pemurah. Yang mengajar (manusia) dengan perantara qalam (pena). Dia mengajarkan manusia apa yang tidak diketahuinya.

Makna qalam (pena) adalah wujud itu sendiri, seperti air, sungai, udara, gunung, hewan, manusia, atom, molekul, bumi dan sebagainya. Semua pena itu bisa menulis dan tulisan itu disebut perilaku yang bisa dibaca manusia.
Manusia merekam, memahami serta menginterprestasikannya. Orang yang cerdas mereka yang mampu mengapresiasi kehidupan itu sendiri, serta mencari tahu dan jawaban atas berbagai persoalan kehidupan. Mereka inilah orang-orang yang berhasil mengak-tualisasikan kecerdasan spiritualnya secara optimal. Berbeda dengan kecerdasan umum (IQ) yang memandang dan menginterpretasikan sesuatu dalam kategori kuantitatif (data dan fakta) serta gejala (fenomena). Kecerdasan spiritual memandang dan menginterpretasikan sesuatu tak hanya bersifat kuantitatif dan fenomena, tetapi melangkah lebih jauh dan mendalam, yakni pada dataran epitemik dan ontologis (substansial). Kecerdasan spiritual juga berbeda dengan kecerdasan emosional, dalam melihat dan menyadari diri. Pada kecerdasan emosional, manusia dilihat dan dianalisis dalam batas-batas psikologis dan sosial, sementara pada kecerdasan spiritual, manusia diinterpretasi dan dipandang eksistensinya sampai pada dataran noumenal (fitriyah) dan universal.

Untuk mengembangkan kecerdasan spiritual maka diperlukan IQ dan EQ karena tanpa kecerdasan itu maka SQ tidak bisa berjalan dengan baik. IQ, EQ dan SQ mem-punyai keterkaitan satu dengan lainnya. Selanjutnya dianjurkan memperbanyak ibadah-ibadah sunnah. Ibadah sunah dapat diibaratkan sebagai suatu pendakian transedental. Ibadah-ibadah sunah yang dilakukan tak ubahnya seperti perjalanan untuk mendapatkan dan mendekati cahaya Ilahi. Selanjutnya adalah takziyatun Nafs (penyucian diri) agar cahaya Ilahi dapat menembus dan menggerakkan kecerdasan kita.

Agustian (2002) menjelaskan bahwa kecerdasan spiritual adalah kemampuan untuk memberi makna terhadap setiap perilaku dan kegiatan, melalui langkah-langkah dan pemikiran yang bersifat fitrah. Selanjutnya akan menuju hanif dan memiliki pemikiran tauhidi (interalistis), serta berprinsip hanya kepada Allah SWTHal ini sesuai dengan Al-Qur'an surat ArRum ayat 30: "Maka hadapkanlah wajahmu dengan lurus kepada agama (Allah); (tetaplah atas) fitrah Allah yang telah menciptakan manusia menurut fitrah itu, tidak ada perubahan pada fitrah itu. (itulah) agama yang lurus; tetapi kebanyakan manusia tidak mengetahui." (QS. Ar-Rum : 30) (Depag, 1996)

Kecerdasan ini kita sebut kecerdasan spiritual karena kecerdasan ini bersumber dari fitrah manusia itu sendiri. Kandungan kecerdasan spiritual yang terpenting adalah kesadaran 
tentang iman dan iman yang disadarinya itu sendiri. Memiliki kecerdasan spiritual berarti memiliki visi dan tujuan hidup yang benar. Kecerdasan ini tidak dibentuk melalui kursus karena merupakan aktualisasi dari fitrah itu sendiri. Manusia juga harus melakukan 'pendakian' yang bersifat transendental atau menjalani hidup spiritual intensif. Kecerdasan spiritual ini akan mengalami aktualisasi dirinya yang optimal jika hidup manusia berdasarkan visi dasar dan misi utamanya, yakni sebagai 'abid' dan sekaligus sebagai khalifah Allah SWT di bumi.

Zohar dan Marshal (2002) menggambarkan diri yang cerdas spiritual memiliki pemahaman yang mendalam atas keterkaitan dalam kehidupan dan seluruh usahanya. Ia memiliki rasa kemanusiaan dan rasa syukur kepada sumber yang darinya ia dan semua lainnya berasal. Kecerdasan spiritual dapat diibaratkan sebagai permata yang tersimpan dalam batu. Allah senantiasa mencahayai permata itu, seperti diungkapkan dalam Al-Qur'an dalam surat An-Nur ayat 35:

"Allah (pemberi) cahaya (kepada) langit dan bumi. Perumpamaan cahaya Allah, adalah seperti sebuah lubang yang tak tembus, yang didalamnya ada Pelita besar. Pelita itu didalam kaca (dan) kaca itu seakan-akan bintang (yang bercahaya) seperti mutiara, yang dinyalakan dengan minyak dari pohon yang banyak berkahnya (yaitu) pohon zaitun yang tumbuh tidak disebelah baratnya, yang minyaknya (saja) hampir-hampir memerangi, walaupun tidak disentuh api. Cahaya diatas cahaya (berlapislapis). Allah membimbing kepada cahaya-Nya siapa yang Dia kehendaki, dan Allah memperbuat perumpamaan-perumpamaan bagi manusia dan Allah Maha Mengetahui segala sesuatu." (QS. An-Nur : 35)(Depag, 1996)

Suharsono (2005) menjelaskan bahwa kecerdasan spiritual berarti kemampuan kita untuk dapat mengenal dan memahami kita sepenuhnya melalui wahyu yang diturunkan baik bersifat tekstual (Al-Quran) maupun alam semesta. Dengan memiliki kecerdasan spiritual berarti kita memahami sepenuhnya makna dan hakikat yang kita jalani dan kemanakah arah dan tujuan hidup kita. Kecerdasan spiritual akan menjadikan manusia memiliki integritas moral yang tinggi, shaleh, peduli terhadap sesama dan mempunyai integritas spiritual.
Zohar dan Marshal (2002) mengemukakan enam jalan untuk mengembangkan kecerdasan spiritual di sekolah, diantaranya :

\section{a. Melalui pemberian tugas}

Memberikan ruang kepada siswa untuk melakukan kegiatannya sendiri akan melatih mereka memecahkan masalahnya sendiri. Guru tidak perlu khawatir murid akan melakukan kesalahan karena dalam setiap kegiatan belajar mengajar, anak dijelaskan manfaat mengapa anak perlu mempelajari hal tersebut sehingga dia sendiri memiliki motivasi untuk memperdalam materi tersebut.

\section{b. Melalui pengasuhan}

Pendidik perlu menciptakan suasana kelas penuh dengan kegembiraan dimana setiap peserta didik saling menghargai. Beragam karakter yang adadi dalam kelas memungkinkan muncul konflik atau pertengkaran. Namun itu adalah kesempatan bagi pengembangan kecerdasan spiritual peserta didik karena guru dapat mengarahkan peserta didiknya memahami akar permasalahan, perasaan masing-masing serta mencari pemecahan masalah yang terbaik. Setiap konflik atau masalah yang muncul harus dapat dijadikan momentum oleh guru bagi seluruh peserta didik untuk pengembangan kecerdasan spiritual mereka.

c. Melalui pengetahuan

Pendidikan perlu mengembangkan pelajaran dan kurikulum sekolah yang mampu mengembangkan realisasi diri peserta didik seperti kurikulum yang dapat melatih kepekaan siswa terhadap berbagai masalah aktual. Peserta didik diajak berefleksi tentang makna, bagaimana dia dapat ikut serta memecahkan masalah tersebut. Peristiwa seperti bencana alam, banjir dan tanah longsor dapat dijadikan bahan belajar melatih kepekaan terhadap nilai dan makna kemanusiaan sehingga mereka dapat diajak berefleksi, menyadari dan ikut merasakan bagaimana berada seperti orang lain.

d. Melalui perubahan pribadi (kreatifitas)

Dalam setiap kegiatan belajar mengajar seharusnya guru merangsang kreatifitas peserta didiknya. Anak-anak itu sebenarnya memiliki imajinasi dan daya cipta yang sangat tinggi. Mereka dapat menciptakan peraturan kelas dan peraturan sekolahnya sendiri dengan baik dan ideal. 
Guru tinggal menciptakan kondisi dimana daya kreatifitas yang sudah ada dalam diri mereka itu dapat diekspresikan dengan penuh makna.

e. Melalui persaudaraan

Hukuman fisik dan olok-olok, perkelahian dan saling mengejek antar murid perlu dihindari karena dapat menghambat kecerdasan spiritual (SQ). Sebaliknya guru perlu mendorong setiap peserta didik untuk saling menghargai dan saling memahami pendapat dan perasaan masing-masing. Bila terjadi konflik, murid perlu diajak berdialog untuk mencari cara pemecahan konflik yang dapat diterima semua pihak. Setiap koflik merupakan kesempatan untuk mengembangkan kecerdasan spiritual. Lingkungan seperti itu membantu peserta didik mengembangkan kemampuan mengelola konfliknya sendiri.

f. Melalui kepemimpinan yang penuh pengabdian

Guru menjadi model pemimpin yang diamati oleh peserta didiknya. Pengalaman peserta didik bagaimana dilayani dan dipahami sungguh-sungguh oleh gurunya adalah pengalaman secara tidak langsung mengajarkan kepada peserta didik bagaimana layaknya perilaku seorang pemimpin. Pemimpin yang efektif itu adalah yang mengerti dan memahami dan melayani kepentingan bawahannya.

Sedangkan menurut Ngermanto (2005) ada tujuh langkah dalam mengembangkan kecerdasan spiritual, yaitu :

\section{a. Menyadari situasi}

Kita harus menyadari di mana kita dan keadaan kita sekarang. SQ sampai pada memikirkan segala hal dan menilai diri sendiri serta perilaku diri dari waktu ke waktu.

\section{b. Ingin berubah}

Jika renungan mendorong untuk kita menghasilkan perilaku, hubungan, kehidupan atau hasil kerja yang lebih baik, maka kita harus berjanji dalam hati untuk berubah. Ini akan menuntut kita memikirkan secara jujur apa yang harus kita tanggung dari perubahan itu dalam bentuk energi dan pengorbanan.

c. Mengenali diri
Kita harus mengenali diri sendiri, letak pusat kita dan motivasi kita yang paling dalam.

d. Menyingkirkan hambatan

Hambatan seperti kemarahan, kerakusan, rasa bersalah, malas dll harus dihindarkan melalui tindakan-tindakan seperti kesadaran atau ketetapan hati.

e. Disiplin

Pada tahap ini kita perlu menyadari berbagai kemungkinan untuk bergerak maju. Selain itu harus bisa berkomitmen untuk hal yang bermanfaat.

f. Maknai terus-menerus

Kita harus menetapkan hati pada satu jalan dalam kehidupan dan berusaha menjaga pusat sementara kita melangkah di jalan itu. Kita harus bisa memaknai setiap apa yang kita lakukan dan setiap situasi. Menjalani hidup di jalan menuju pusat berarti mengubah pikiran dan aktifitas sehari-hari menjadi ibadah terus-menerus, memunculkan kesucian alamiah yang ada dalam situasi yang bermakna.

\section{g. Hormati mereka}

Belajar menghormati orang lain yang berjalan selain di jalan kita pilih karena apa yang ada dalam diri kita sendiri yang akan dimasa mendatang mungkin perlu mengambil jalan lain.

Berikutnya Sukidi (2004) menjabarkan langkah-langkah untuk mengasah SQ antara lain :

a. Kenalilah diri anda karena orang yang sudah tidak bisa mengenali dirinya sendiri akan mengalami krisis makna hidup maupun krisis spiritual.

b. Lakukan intropeksi diri. Kita perlu melakukan intropeksi diri karena mungkin kita telah melakukan kesalahan, kecurangan atau kemunafikan terhadap orang lain.

c. Aktifkan hati secara rutin dengan cara mengingat Tuhan. Mengingat Tuhan, membuat hati kita menjadi damai yang dapat dilakukan dengan cara dzikir, tafakur, shalat tahajud, dll.

d. Menemukan keharmonisan dan ketenangan hidup setelah mengingat sang Khalik maka kita dapat merasakan kepuasan tertinggi berupa kedamaian dalam hati dan jiwa. Kita akan men- 
capai keseimbangan dalam hidup dan merasakan kedalaman spiritual.

\section{METODE PENELITIAN}

Studi yang meneliti tentang pengembangan kecerdasan spiritual siswa di sd islam tompokersan lumajang ini menggunakan pendekatan kualitatif.

Sumber data penelitian ini adalah kepala sekolah, guru dan siswa. Penelitian dilakukan dengan wawancara secara intensif dan mendalam (in-depth-interview) yang memfokuskan pada bagaimana pikiran, perasaan dan tindakan atau kegiatan responden pada saat di lingkungan sekolah.

Data yang terkumpul berupa hasil wawancara (verbatim), catatan lapangan dari observasi serta foto-foto kegiatan yang dilakukan.

Observasi ini dilakukan untuk mengetahui bagaimana upaya pengembangan kecerdasan spiritual siswa di SD Islam Tompokersan Lumajang. Selanjutnya adalah wawancara dengan para repondent mengenai upaya pengembangan kecerdasan spiritual meliputi arah pengembangan, program-program pengembangan metode pengembangan, pihak-pihak yang terkait serta sarana dan fasilitas yang mendukung serta problematika yang dihadapi.

Data yang sudah diambil akan dianalisa dengan mengaitkan antara jawaban yang diberikan responden dengan kajian pustaka yang ada.

\section{HASIL DAN PEMBAHASAN}

Upaya yang dilakukan dalam mengembangkan kecerdasan spiritual siswa di SDI Tompokersan Lumajang dilakukan dengan beberapa cara yaitu :

\section{Tafakur kepada Allah}

Tafakur yang dilakukan adalah dengan memikirkan tentang kejadian alam semesta, bahwa Allah menciptakan semua ini dengan mudah dengan berbagai macam benda yang dapat dimanfaatkan oleh manusia. Dengan demikian maka siswa akan berfikir bahwa Allah Maha Kuasa dan Maha Karya, sehingga akan menimbulkan rasa iman yang lebih kuat pada siswa. Selain itu siswa juga diajak untuk selalu mengingat Allah setiap hari serta memberikan manfaat dari setiap perbuatan yang dila-kukannya. Contohnya mengingat Tuhan dengan mensyukuri nikmat yang telah diberikan Allah kepadanya hari ini. Setiap siswa akan berpikir bahwa Allah Maha Kaya, dan Maha Pengasih kepada semua hambaNya. Dalam upaya ini yang ditekankan adalah bagaimana anak mengetahui makna dan nilai yang terkandung di dalamnya. Tafakur ini juga dilakukan dengan cara muhasabah atau perenungan. Tujuannya adalah agar siswa mampu mengintropeksi diri mereka selama ini, apakah bermanfaat hidup mereka ataukah banyak kerugian yang telah mereka lakukan. Dengan demikian maka siswa akan lebih berhati-hati dalam melangkah sehingga makna dari setiap perbuatan dapat mereka raih.

2. Melakukan ibadah-ibadah sunah

Hal lain yang dilakukan adalah membiasakan pada siswa melakukan ibadah-ibadah sunah dalam kehidupan sehari-hari mereka. Ibadah sunnah merupakan media dalam pengembangan kecerdasan spiritual. Untuk itu sangat dianjurkan untuk melaksanakan ibadah-ibadah sunah. Ibadah-ibadah sunah yang dilakukan oleh siswa SDI Tompokersan Lumajang adalah melaksanakan shalat dhuha secara berjamaah, mengaji Al-Qur'an, dll.

3. Dzikir kepada Allah

Untuk mengembangkan kecer-dasan spiritual siswa maka dilakukan dzikir agar siswa selalu mengingat Allah setiap hari. Dzikir dilakukan setiap selesai shalat berjamaah yang dilakukan di sekolah yaitu setelah shalat dhuha, shalat dhuhur dan shalat ashar. Selain itu juga dengan membaca asmaul husna agar siswa mampu mengingat dan mengetahui nama-nama Allah serta dapat mengaplikasikannya dalam kehidupan mereka. Dzikir dan bacaan asmaul husna dilakukan bersamasama.

Upaya pengembangan kecerdasan spiritual siswa tidak akan berjalan maksimal tanpa adanya program-program yang diadakan untuk mendukung pengembangan tersebut. Maka dari itu diperlukan program-program atau kegiatankegiatan yang dapat dilakukan siswa sebagai sarana untuk mengembangkan kecerdasan spiritual mereka. Adapun program yang diadakan SDI Tompokersan Lumajang sebagai upaya dalam pengembangan kecerdasan spiritual siswa adalah sebagai berikut:

\section{1) Program Terstruktur}

Pogram terstruktur ini dibagi menjadi dua yaitu kegiatan di dalam kelas dan kegiatan di luar kelas. Kegiatan di dalam kelas bisa dilakukan oleh guru dengan cara 
mengaitkan materi pelajaran dengan agama. Hal ini dilakukan oleh Bapak Mabrur yang mengatakan :"Sayaselalu mengaitkan materi pelajaran dengan kehidupan seharihari. Misalnya tentang toleransi. Betapa pentingnya sifat toleransi bagi kehidupan manusia. Bagaimana kalau tidak ada sifat toleransi sesama manusia? Dari sini siswa diajak berpikir akan peran penting aplikasi sifat toleransi dalam kehidupan kita seharihari”.Dengan demikian maka siswa tidak hanya mendapatkan teori dari pelajaran yang diperoleh. Akan tetapi siswa juga diajarkan bagaimana mengaplikasikan teori-teori tersebut dalam kehidupan mereka sehari-hari.

Selain itu kegiatan lain dilakukan di dalam kelas adalah mengaji atau Tadarus Al-Qur'an. Mengaji atau Tadarus AlQur'an dilaksanakan dua kali dalam sehari. Pertama dilaksanakan sebelum mulai pelajaran yaitu pada pukul 06.45-06.55 WIB dan keduadilaksanakan pada pukul 14.25-15.15 WIB yakni setelah berakhirnya jam pelajaran terakhir sampai waktu shalat ashar. Kegiatan ini dilakukan oleh setiap siswa di dalam kelas masing-masing dengan dipantau dan dibimbing oleh guru mata pelajaran jam pertama. Materinya adalah juz 'amma. Maksud dari mengaji ini adalah untuk melatih siswa membiasakan membaca Al-Qur'an, praktek dari pelajaran serta nantinya siswa diharapkan hafal surat-surat pendek. Sedangkan untuk sesi kedua setelah pelajaran terakhir, materi mengaji lebih ditekankan pada Iqra' Sebelum mengaji pada jam ini dilakukan seleksi terlebih dahulu pada siswa. Siswa di tes satu persatu bagaimana bacaan mereka. Jika belum lancar maka ditentukan untuk ikut mengaji iqra' sesuai dengan kemampuan bacaannya. Sedangkan yang sudah lancar maka diarahkan ke Al-Qur'an dan ke minat bakat.

Kegiatan berikutnya adalah shalat berjamaah sebagai salah satu program atau kegiatan yang dilaksanakan untuk pengembangan kecerdasan spiritual siswa adalah shalat berjamaah di sekolah. Shalat berjamaah ini wajib diikuti bagi setiap siswa mulai dari kelas satu sampai siswa kelas tiga. Adapun shalat berjamaah yang dilaksanakan adalah shalat dhuha, shalat duhur dan shalat ashar. Pelaksanaan shalat ber- jamah ini dipimpin oleh beberapa guru yang bertugas sebagai imam dan sebagai guru pendamping. Guru pendamping memantau shalat siswa. Jika ada siswa yang kurang benar atau mengganggu dalam shalat maka akan diberi nasehat dengan cara disuruh untuk shalat sendiri kemudian ditanya mengapa melakukan hal yang tidak benar dalam shalat. (lihat lampiran). Muadzin dan doa setelh shalat dilakukan oleh siswa sesuai dengan jadwal yang telah dibuat.

Berikutnya adalah shalat dhuha yang dilaksanakan pada pukul 08.15-08.35 WIB, setelah dua jam pelajaran mengajar. Tujuannya adalah untuk melatih dan membiasakan diri siswa untuk melaksanakan sunah Nabi Muhammad SAW. Serta sebagai sarana dan perwujudan untuk praktek siswa dari pelajaran yang telah diperolehnya. Selain itu shalat dhuhur dan ashar dilaksanakan di sekolah dan sifatnya diwajibkan berjamaah bagi seluruh siswa. Shalat dhuhur dilaksanakan pada pukul 12.10-13.05 WIB. Setelah itu dilanjutkan dengan istirahat untuk makan siang. Sedangkan shalat ashar dilaksanakan pada pukul 15.15-15.25 WIB. Tujuannya adalah agar siswa membiaskan diri untuk sholat berjamaah karena selain pahalannya yang berlipat juga karena nilai sholat berjamaah sangat tinggi. Misalnya nilai persatuan antar umat Islam yang ada di dalam sholat berjamaah.

Kegiatan lainnya yang juga dilakukan di dalam kelas adalah membaca asmaul husna yang bertujuan agar siswa mengetahui dan mampu memaknai sifat dari nama-nama Allah yang berjumlah 99 dan mengaplikasikannya dalam kehidupan sehari-hari. Misalnya sifat Ar-Rahman (Maha Pengasih) Allah. Bagaimana siswa dapat melihat akan sifat pengasih Allah kepada semua makhluknya tanpa terkecuali. Bagaimana jika dibandingkan dengan sifat pengasih makhluknya. Dari sini maka siswa akan mengetahui bahwa sangat penting sekali makna kasih sayang dalam kehidupan ini.

Adapun kegiatan di luar kelas yang dilaksanakan sebagai upaya dalam pengembangan kecerdasan spiritual siswa adalah muhasabah, pondok ramadhan, dan Peringatan Hari Besar Islam (PHBI) dan 
Peringatan hari Besar Nasional (PHBN). Muhasabah adalah intropeksi diri atau perenungan Muhasabah dilakukan pada akhir tahun dan pada waktu bulan ramadhan dengan memutar film-film yang bisa memberi teladan bagi siswa dan dengan jalan istighasah yang dilakukan secara bersama-sama baik kepala sekolah, guru, karyawan dan siswa. Muhasabah ini dilakukan agar siswa dapat merenungkan apa yang telah diperbuatnya selama ini. Apakah sudah banyak manfaat dari perbuatan yang dilakukannya ataukah banyak ruginya. Dengan intropeksi diri maka siswa dapat memperbaiki dirinya kearah yang lebih baik.

Berikutnya adalah peringatan hari besar Islam (PHBI) dan peringatan hari besar nasional PHBN. Tujuannya adalah agar siswa bisa memahami nilai-nilai dan makna yang terkandung dari setiap peristiwa yang terjadi. PHBI dan PHBN juga merupakan saran bagi siswa untuk menampilkan kreasi sesuai dengan bakat mereka masing-masing. Seperti peringatan Maulid Nabi Muhammad SAW, Isra' Mi'raj, Nuzulul Qur'an, dan tahun baru Hijriyah (1 muharam), hari ibu, hari pahlawan, dll.

\section{2) Program Tak Berstruktur}

Kegiatan dalam program tak berstruktur ini adalah kegiatan ekstrakurikuler yang dilakukan di luar jam pelajaran dan pada waktu libur sekolah. Adapun kegiatan ekstrakurikuler yang ada di SDI Tompokersan Lumajangadalah Palang merah remaja (PMR), pramuka, teater, bidang olah raga, meliputi bulu tangkis, ranang, dan tapak suci serta Qiro'ah.

Pengembangan kecerdasan spiritual siswa di SDI Tompokersan Lumajang dilakukan melalui beberapa cara yaitu :

a. Melalui jalan tugas

Cara yang dipakai dalam metode ini adalah memberi tugas pada siswa tentang suatu topik yang harus dikaji oleh siswa. Penugasan ini biasanya berbentuk portofolio, misalnya mengamati akhlak terpuji orang-orang yang ditemuinya hari itu.

b. Melalui jalan pengasuhan

Siswa adalah pribadi yang mempunyai perbedaan antara siswa yang satu dengan siswa yang lainnya. Untuk itu masalah mempunyai peluang yang besar muncul di dalamnya. Ketika terjadi konflik baik dari diri siswa itu sendiri maupun konflik antar siswa guru memberikan arahan dan bimbingan untuk mencari akar dari setiap permasalahan yang ada serta mencari jalan keluar yang baik yang tidak merugikan semua pihak, baik melalui pendekatan interpersonal maupun antar personal.

c. Melalui jalan pengetahuan

Jalan pengetahuan ini dilakukan dengan cara mengajak siswa merefleksikan kejadian-kejadian aktual seperti bencana alam banjir, gempa bumi, longsor, dll. Dari sini siswa diharapkan bisa merasakan penderitaan orang lain serta dapat menolong mereka. Siswa SDI Tompokersan Lumajang sangat peduli dengan masalahmasalah tersebut. Hal ini dapat dilihat dari usaha siswa membantu korban bencana seperti bencana tsunami di Aceh, baksos dengan pemberian hewan Qurban di desa Kacur, dll. Selain itu cara lain yang digunakan adalah memutar film yang bisa dijadikan pelajaran bagi siswa. Dengan tujuan agar siswa mengetahui nilai-nilai yang terkandung didalamnya.

d. Melalui jalan perubahan pribadi (kreatifitas)

Pada dasarnya setiap siswa mempunyai daya cipta atau kreatifitas yang tinggi. Bakat dan minat siswa tidak dibiarkan terpendam sehingga siswa tidak dapat berkembang secara optimal. Siswa diberi kebebasan dalam menyalurkan kreatifitasnya. Misal karya-karya yang berhubungan dengan pelajaran tertentu yaitu kaligrafi tentang kekuasaan Tuhan sebagai realisasi dari pelajaran akidah akhlak. Selain itu ada banyak kreatifitas siswa yang dikembangkan yaitu karya ilmiah, membuat Cerpen gambar, madding, dll.

e. Melalui jalan persaudaraan

Sikap saling tolong menolong dan saling menghargai selalu ditanamkan pada diri setiap siswa. Ketika terjadi masalah antar sesama teman, siswa berusaha menyelesaikan masalahnya sendiri dengan jalan dialog untuk memahami perasaan masing-masing sebelum minta bantuan kepada guru. Jika teman melanggar peraturan maka siswa yang lain saling mengingatkan. Dengan cara seperti ini maka kecerdasan spiritualsiswa dapat 
berkembang dengan baik karena mereka mampu memahami dan menghargai orang lain.

f. Melalui jalan kepemimpinan yang penuh dengan tanggung jawab

Guru adalah sosok figur contoh bagi siswa yang ditemuinya setiap hari. Suri tauladan yang diajarkan guru kepada siswa secara tidak langsung sangat berpengaruh terhadap kehidupan siswa. Untuk itu guru harus bisa menjadi contoh yang baik bagi siswa.

Perpustakaan merupakan salah satu sarana dan fasilitas yang ada di sekolah sebagai pasar informasi, pusat belajar mengajar sekaligus tempat menyalurkan bakat dan kreatifitas siswa. Penggunaan perpustakaan dalam rangka mengembangkan kecerdasan spiritual siswa meskipun buku-buku yang ada terbatas. Fasilitas penting lainnya adalah musholla (aula) yang digunakan untuk sholat dhuha, sholat dhuhur, sholat ashar, mengaji serta kegiatan-kegiatan lainnya. Berikutnya adalah laboratorium komputer yang bisa digunakan siswa untuk mengembangkan pengetahuan mereka dengan bimbingan dari guru.

Pihak sekolah serta komponen yang ada di dalamnya mempunyai peran yang sangat penting dalam pengembangan kecerdasan spiritual siswa. Peran siswa tidak kalah penting dalam berbagai kegiatan yang telah dirancang oleh pihak sekolah baik kepala sekolah maupun para guru.Kepala sekolah bersama-sama dengan semua staff guru bekerjasama dalam membantu menciptakan suasana yang mendukung siswa melakukan berbagai kegiatan yang bersifat spiritual keagamaan.

Berikutnya adalah peran orang tua juga sangat penting dalam mengontrol tingkah laku dan perkembangan siswa di rumah sehingga secara optimal pengembangan akan berjalan dengan baik. Dengan adanya rapor bulanan maka orang tua dapat dengan mudah mengetahui perkembangan anaknya Terakhir adalah keterkaitan masyarakat melalui saran dan pendapat tentang perilaku atau akhlak siswa dalam bermasyarakat ketika pihak sekolah mengadakan acara-acara seperti memperingati Isra' mi'raj, Maulid Nabi SAW, dll.

\section{PEMBAHASAN}

SDI Tompokersan Lumajang melakukan sejumlah kegiatan dalam upaya mengembangkan kecerdasan spiritual siswa disana. Pertama, siswa diberikan tugas yang sifatnya portfolio seperti mengamati akhlak terpuji orang-orang yang ditemuinya kemudian mengertikan makna dari akhlak terpuji tersebut. Kegiatan tersebut diharapkan dapat mendorong siswa mandiri dalam melakukan kegiatan pembelajaran mulai dari pengamatan sampai pengertian makna. Hal itu pula yang disampaikan oleh Zohar dan Marshal (2002) bahwa pengembangan kecerdasan spiritual melalui pemberian tugas dapat memberikan ruang kepada siswa untuk melakukan kegiatannya sendiri dan melatih mereka memecahkan masalah.

Kegiatan berikutnya adalah guru memberikan arahan dan bimbingan mencari jalan keluar yang baik dalam menyelesaikan konflik yang terjadi di antara para siswa. Pencarian solusi yang tidak merugikan semua pihak dilakukan melalui pendekatan interpersonal maupun antar personal. Apa yang dikatakan Agustian (2001) adalah menjadi harapan ke depannya dimana para siswa memiliki kesadaran dalam diri yang membuat mereka mampu membedakan yang salah dan yang benar serta bijaksana. Menghadapi konflik tentu membuat siswa berada dalam kondisi yang tidak nyaman maka peran guru sangat penting dalam memberikan arahan dan bimbingan.

Selanjutnya siswa juga diajak untuk merefleksikan kejadian-kejadian aktual seperti bencana alam banjir, gempa bumi, longsor yang terjadi di tanah air. Mereka belajar untuk menggali hikmah dan makna dari berbagai kejadian yang terjadi. Misalnya semua bencana yang terjadi adalah skenario Allah tetapi kita belajar untuk memaknai apa yang terjadi. Kegiatan sosial yang dilakukan bertujuan menanamkan sifat empati pada diri siswa sehingga tumbuh sikap saling tolong-menolong. Zohar dan Marshal (2002) mengatakan bahwa individu yang cerdas spiritualnya memiliki rasa kemanusiaan dan rasa syukur kepada sumber yang darinya ia dan semua lainnya berasal. Apapun yang dihapapi baik itu menyenangkan ataupun tidak harus bisa diyakini dan dimaknai sebagai bahan belajar untuk menjadi semakin bijaksana dan meningkatkan kecerdasan spiritual.Ada pula cara lain yang juga dilakukan untuk membantu pengembangan kecerdasan 
spiritual siswa yaitu melalui kesempatan belajar membuat karya-karya seni seperti kaligrafi, cerpen atau pun karya ilmiah.

Selain itu guru juga berupaya mendorong setiap peserta didik untuk saling menghargai dan saling memahami pendapat dan perasaan masingmasing. Ketika terjadi masalah sesama teman, siswa berusaha menyelesaikan masalahnya sendiri dengan jalan dialog untuk memahami perasaan masing-masing sebelum minta bantuan kepada guru. Jika teman melanggar peraturan maka siswa yang lain saling mengingatkan. Guru juga dapat melakukan melalui kepemimpinan seperti memberikan contoh bagaimana menjadi seseorang yang baik dan berakhlakul karimah.

Apa yang telah dilakukan SDI Tompokersan Lumajang dalam upaya mengembangkan kecerdasan spiritual siswa mereka seperti yang digambarkan oleh Zohar dan Marshal (2002) bahwa kecerdasan spiritual dapat diupayakan pengembangannya melalui sejumlah cara. Adapun tujuan akhir yang diharapkan adalah seperti yang disampaikan oleh Agustian (2001) bahwa dengan memiliki kecerdasan spiritual yang baik maka siswa mampu membedakan yang salah dan yang benar serta bijaksana.

Ada pula sejumlah upaya lainnya yang juga secara konsisten berusaha untuk diterapkan yaitu tafakur kepada Allah yakni memikirkan tentang kejadian alam semesta serta meyakini bahwa Allah menciptakan semua ini agar dapat dimanfaatkan oleh manusia. Tafakur dilakukan dengan cara muhasabah atau perenungan dengan tujuan agar siswa mampu mengintropeksi diri mereka selama ini, apakah bermanfaat hidup mereka ataukah banyak kerugian yang telah mereka lakukan. Hal lain yang juga dilakukan adalah membiasakan pada siswa melakukan ibadah-ibadah sunah dalam kehidupan sehari-hari mereka. Ibadah sunnah merupakan media dalam pengembangan kecerdasan spiritual. Terakhir adalah dzikir kepada Allah untuk mengembangkan kecerdasan spiritual siswa maka dilakukan dzikir agar siswa selalu mengingat Allah setiap hari.

Sukidi (2004) menegaskan bahwa kenalilah diri, lakukan intropeksi diri, aktifkan hati secara rutinmengingat Tuhan dengan cara dzikir, tafakur, shalat tahajud, dll. Demikian pula Suharsono (2005) yang mengatakan bahwa untuk mengembangkan kecerdasan spiritual dapat dilakukan dengan metode penemuan dan metode dzikir. Metode penemuan digunakan untuk menemukan hidup yang bermakna serta menjalani hidup yang bermakna. Metode ini dapat diperoleh dengan cara tafakur dan merumuskan misi hidup. Dengan memikirkan hakekat kejadian diri dan alam semesta maka akan memunculkan rasa ketakjuban dan pengagungan kepada Allah. Tafakur akan nikmat Allah akan mendorong kita untuk mensyukuri dan meningkatkan ibadah dan amal shaleh sebagai wujud kecintaan kepada Allah.

Sejumlah program yang diadakan dalam upaya pengembangan kecerdasan spiritual siswa juga menuju individu cerdas yang seperti dikatakan Nafis (2006) 'cerdas' dalam mengelola dan mendayagunakan makna-makna, nilai-nilai, dan kualitas-kualitas kehidupan spiritualnya. Kegiatan seperti tadarus Al-Qur'an, membaca asmaul husna, muhasabah, pondok ramadhan, dan Peringatan Hari Besar Islam (PHBI) dan Peringatan hari Besar Nasional (PHBN) adalah bertujuan untuk mendorong siswa memiliki kemampuan untuk memberi makna terhadap setiap perilaku dan kegiatan.

Agustian (2002) juga menegaskan bahwa hal itu dapat dilakukan melalui langkah-langkah dan pemikiran yang bersifat fitrah. Langkah fitrah dapat dimulai oleh guru dengan cara mengaitkan materi pelajaran dengan agama, mengaji atau tadarus Al-Qur'an di kelas, shalat berjamaah dan membaca asmaul husna. Membaca asmaul husna bertujuan agar siswa mengetahui dan mampu memaknai sifat dari nama-nama Allah yang berjumlah 99 dan mengaplikasikannya dalam kehidupan sehari-hari.

Zohar dan Marshal (2002) menggambarkan bagaimaan SQ memungkinkan manusia untuk menjadi kreatif sehingga berbagai kegiatan ekstrakurikuler sangat mendukung dalam pengembangan kecerdasan spiritual siswa. Contoh kegiatan ekstrakurikuler seperti palang merah remaja (PMR), pramuka, teater, bidang olah raga, meliputi bulu tangkis, ranang, tapak suci dan Qiro'ah.

Setiap upaya yang dilakukan pasti mengalami problema-problema yang menjadi penghambat dalam mencapai upaya tersebut. Fasilitas mushola yang luas dan permanen belum dimiliki oleh SDI Tompokersan Lumajang dan itu menyebabkan guru tidak dapat melakukan banyak kegiatan untuk menunjang pengembangan kecerdasan spiritual siswa.

Adapun upaya yang dilakukan pihak sekolah adalah menjadikan aula sebagai musholla agar aktifitas siwa dalam mengembangkan kecer- 
dasan spiritual dapat berjalan secara optimal. Masalah lainnya yang juga dihadapi SDI Tompokersan Lumajang adalah disiplin siswa yang tentunya sangat berpengaruh terhadap semangat dan perkembangan kecerdasan spiritual siswa. Banyak siswa yang masih kurang disiplin dalam melaksanakan semua kegiatan yang telah diprogramkan seperti tidak tepat waktu dalam melaksanakan sholat dhuha, sholat duhur dan sholat ashar berjama'ah, dll. Hal ini dapat menghambat pengembangan kecerdasan spiritual siswa karena kurangnya kesaran dari diri siswa itu sendiri.

Namun untuk mengatasi hal tersebut, guru selalu memberikan bimbingan dan arahan kepada siswa, sehingga mereka tidak berjalan pada jalan yang salah. Usaha yang dilakukan adalah dengan melakukan pendekatan interpersonal maupun antarpersonal terhadap siswa. Tujuannya adalah supaya siswa bisa mengontrol dirinya sendiri serta mengetahui nama yang harus dilakukan dan nama yang harus ditinggalkan. Selain itu, untuk meningkatkan disiplin siswa maka Kepala Sekolah dan semua guru memberikan contoh secara langsung kepada semua siswa tentang kedisiplinan. Misalnya datang tepat waktu, berpakaian rapi, menjaga kebersihan, dll.

Ngermanto (2005) mengatakan bahwa menyingkirkan hambatan seperti rasa malas, bersikap disiplinn dan berkomitmen mendorong kita menghasilkan perilaku, hubungan, kehidupan atau hasil kerja yang lebih baik. Suharsono (2005) juga menmbahkan bahwa ada dua hal yang perlu dilakukan untuk mengembangkan kecerdasan spiritual yaitu melakukan latihan yang bersifat intelektual dan menjalani hidup secara spiritual.

Logika dapat mempertajam dan menguatkan analisa atas ide inspirasi yang timbul sedangkan beribadah, menjalankan hal-hal yang disunahkan, serta menjauhi hal-hal yang subhat, akan mendorong pendakian transendental, menuju "kedekatan" Ilahi. Apa yang diupayakan oleh pihak sekolah SDI Tompokersan Lumajang juga membantu para siswa untuk melatih diri mereka dalam membentuk sikap disiplin dalam melakukan kegiatan positif seperti ibadah.

SDI Tompokersan Lumajangjuga menerapkan sistem poin bagi siswa yang melanggar peraturan sekolah. Banyaknya poin yang diberikan pada siswa tergantung dari pelanggaran yang dilakukan siswa sesuai dengan ketentuan dari sekolah. Hal ini sangat mendukung untuk mengontrol perilaku siswa.
Selain itu perkembangan kecerdasan spiritual siswa dapat dilihat di dalam buku dan kemajuan dan peningkatan Imtaq. Semua siswa memiliki buku tersebut. Isi buku tersebut adalah mengenai pelaksanaan sholat fardhu yang di tanda tangani oleh guru. Dengan adanya fasilitas diatas maka arah pengembangan kecerdasan spiritual siswa akan terlaksana dengan baik disamping peran dari pihak sekolah, keluarga dan masyarakat sekitar.

Pengawasan, bimbingan dan pengarahan yang dilakukan guru terhadap para siswa saat dalam melakukan kegiatan sholat berjamaah adalah bentuk upaya bantuan bagi peningkatan kecerdasan spiritual siswa. Sholat berjamaah yang dilakukan bersama adalah salah satu langkah yang bersifat fitrah karena mengarahkan siswa agar dekat pada Allah. Agustian (2002) telah menjelaskan bahwa kecerdasan spiritual adalah kemampuan untuk memberi makna terhadap setiap perilaku dan kegiatan, melalui langkah-langkah yang bersifat fitrah. Semua siswa setelah melalui berbagai kegiatan yang sifatnya fitrah diharapkan mampu mendapatkan hikmah dari apa yang telah dijalani.

Suharsono (2005) mengatakan bahwa kecerdasan spiritual tercermin dari kemampuan mengenal dan memahami wahyu Allah baik yang bersifat tekstual (Al-Quran) maupun alam semesta. Kegiatan membaca surat-surat pendek dari juz amma adalah contoh upaya peningkatan kecerdasan spiritual siswa. Hafalan surat pendek yang dikuasai siswa akan membuat mereka dekat dengan wahyu-wahyu Allah. Penguasaan suratsurat pendek akan membuat siswa belajar sedikit demi sedikit arti dan makna dari wahyu yang diturunkan Allah. Demikian pula dengan bacaan asmaul husna yang tentunya akan semakin menanamkan sifat-sifat Allah pada diri para siswa. Membaca setiap hari akan membuat para siswa tidak hany mengerti artinya tetapi lebih dari itu diharapkan mereka semakin rindu pada Tuhannya yaitu Allah SWT.

Peran siswa dalam menjalani kegiatan hafalan yang telah dirancang sekolah maupun para guru tentunya tidk luput dari kondisi para siswa yang terkadang rajin atau malas. Hal itu menjadi tantangan baik bagi siswa maupun guru untuk mengasah kecerdasan spiritual mereka. Zohar dan Marshall (2002) mendefinisikan kecerdasan spiritual untuk menghadapi dan memecahkan persoalan makna dan nilai. Apa makna dari semua sikap yang dilakukan seperti malas atau rajin akan dapat dijabarkan oleh guru. 
Siswa dapat dibantu untuk mengambil hikmah dari apa yang dilakukan seandainya mereka bersikap rajin atau malas dengan memberikan gambaran konsekuensi yang akan diterima. Nilai apa yang juga harus dimiliki dalam melakukan semua kegiatan yang diwajibkan sekolah juga akan sedikit demi sedikit tertanam pada diri siswa. Nilai istiqomah adalah sa;ah satu contoh agar mereka dapat terus konsisten menjada kondisi diri. Malas bisa datang pada siapapun namun kemampuan menarik makna dari semua tindakan yang dipilih adalah kecerdasan spiritual yang diharapkan.

Selanjutnya adalah deskripsi Nafis (2006) tentang 'cerdas' mengelola dan mendayagunakan kualitas kehidupan spiritual. Itu adalah salah satu definisi kecerdasan spiritual yang disampaikan sehingga apa yang dialami oleh para siswa di SDI Tompokersan Lumajang adalah sarana mengasah 'cerdas' itu. Berbagai kegiatan lomba keagamaan yang dijadikan sarana peningkatan kecerdasan spiritual siswa tentunya diharap dapat membuat mereka cerdas mengelola potensi yang diberikan Allah serta memanfaatkanya ke jalan yang fitrah.

Kondisi percaya diri berbicara di depan umum adalah salah satu bentuk cerdas spiritual. Zohar dan Marshall (2002) menganggap kecerdasan spiritual sebagai kecerdasan dalam menghadapi persoalan makna dan nilai. Nilai percaya diri telah dapat ditingkatkan dengan kemampuan berbicara di depan umum. Demikian pula dengan lomba-lomba lainnya seperti tartil, adzan, dan MTQ. Semua itu membutuhkan nilai percaay diri yang tinggi sehingga siswa yang mengikuti lomba tersebut akan terlihat cerdas dengan kemampuan menaklukkan rasa takutnya.

Pemutaran film-film sejarah islam yang dilakukan juga bentuk upaya meningkatkan kecerdasan spiritual siswa. Para siswa diharapkan memiliki rasa syukur setelah melihat berbagai sejarah yang ada dalam film. Zohar dan Marshal (2002) mengungkapkan bahwa cerdas secara spiritual artinya memiliki rasa syukur kepada sumber yang darinya ia dan semua lainnya berasal. Sejarah islam yang diperlihatkan melalui film akan menunjukkan betapa Allah maha kaya dan maha kuasa dengan menunjukkan berbagai perubahan di setiap zaman. Rasa syukur para siswa terhadap apa yang telah dimiliki dengan mengambil pelajaran dari apa yang dilihat di film adalah bentuk kecerdasan yang diharapkan.

Guru terlibat dalam kegiatan siswa di sekolah diharapkan memberikan contoh dan sikap tauladan. Agustian (2002) menjelaskan bahwa kecerdasan spiritual adalah kemampuan untuk memberi makna terhadap setiap perilaku dan kegiatan. Jika guru sampai menunjukkan sikap yang tidak terpuji maka itu akan mengganggu siswa dalam mengambil makna dari apa yang dilakukan. Sikap yang tidak baik tentunya akan memberikan hasil yang tidak baik pula.

Agustian (2001) menjelaskan bahwa kecerdasan spiritual adalah kesadaran dalam diri yang membuat manusia mampu membedakan yang salah dan yang benar. Evaluasi yang dilakukan oleh pihak sekolah baik guru bersama juga dengan para siswa tentunya membantu siswa melihat bentuk hal yang salah dan benar. Guru pun mendapatkan kesempatan belajar untuk mencari jalan kreatif untuk menunjukkan benar dan salah pada siswanya.

Upaya lainnya yang dilakukan pihak sekolah adalah memperbaiki proses belajar mengajar sehingga tekanan tidak lagi hanya pada penguasaan jumlah informasitetapi uga bagaimana mencari dan mengolah informasi secara kritis dan kreatif guna pembentukan kepribadian dan sikap yang baik. Sekolah juga perlu memiliki perpustakaan yang menyediakan sumber belajar yang lengkap untuk memperluas wawasan siswa. Keberhasilan sekolah tidak hanya diukur dari kemampuan siswa memenuhi standar nilai intelektual, tapi juga mengembangkan keteladanan (uswatun hasanah) dengan memiliki spiritual yang tinggi. Orang tua dan masyarakat sekitar juga mendorong sekolah untuk bersaing secara sehat denga mengutamakan mutu serta kelima perlu pembudayaan nilai-nilai yang berakar ke Islam dalam keseharian di sekolah dasar oleh seluruh warga.

Selain itu pembinaan moral dapat ditempuh dengan memadukan nilai moral dengan IPTEK. Melalui IPTEK siswa diarahkan untuk menguasai konsep dan prinsip yang kemudian diterapkan dalam pemecahan masalah keilmuan. IPTEK juga merupakan alat pendidikan yang lebih luas untuk melatih logika berpikir lebih tertib,lugas dan sistematis.

Selain itu upaya lainnya yang dilakukan untuk membantu meningkatkan kecerdasan spiritual siswa adalah dengan menciptakan situasi yang konduktif di sekolah. Pertama buat peraturan atau tata tertib dari progam sekolah yang memperhatikan waktu ibadah. Kemudian menyediakan sarana dan prasarana ibadah seperti mushola, perpustakaan dan lain sebagainya. Berikutnya menciptakan lingkungan yang bersih 
dan sehat penampilan dan pergaulan yang harmonis di lingkungan seluruh warga sekolah. Terakhir adalah mengarahkan pembinaan kreatifitas, hobi dan kebiasaan siswa pada hal yang positif dan bernuansa agama.

Diharapkan bahwa di dalam diri setiap siswa yang memiliki kecerdasan spiritual tertanam pemikiran bahwa segala sesuatu yang terjadi di bumi ini adalah kehendak Tuhan. Siswa yang percaya pada kekuasaan dan kebesaran Allah akan berpegang teguh pada firman Allah yang artinya "Niscaya Allah akan meninggikan orang-orang yang beriman dan orang -orang yang diberi ilmu pengetahuan beberapa derajat dan Allah Maha Mengetahui apa yang kamu kerjakan" (QS.Al-Mujadalah,2004:544).

Hal di atas senada dengan apa yang diungkapkan oleh Wahyuni Nafis (2006) bahwa apabila seseorang siswa memiliki kecerdasan spiritual maka siswa akan memiliki moral yang tinggi. Sabar, syukur,dan tawadu' adalah tiga sikap dan prilaku yang harus dapat menjadi amalan. Siswa yang memiliki kecerdasan spiritual akan memiliki prinsip hidup yang benar sehingga tidak mudah dipengaruhi oleh hal-hal eksternal. Selain itu sifat baik sangka, amanah dan silaturahim adalah tiga karakter yang akan meningkatkan kualitas para siswa. Terakhir tawakal, ikhlas dan takwa adalah prinsip yang harus dipegang dengan bersandar sepenuhnya kepada Allah SWT.

Kerjasama para guru baik guru agama islam maupun umum membantu meningkatkan kecerdasan spiritual siswa dalam berbagai program yang dijalankan. Meskipun penyediaan media pembelajaran belum maksimal namun sudah mampu menjawab masalah-masalah siswa melalui pembelajaran dan kegiatan-kegiatan keagamaan yang ada. Hal itu mendorong semua warga sekolah baik siswa maupun guru dapat membiasakan diri dengan perilaku yang fitrah. Berbagai kegiatan yang sifatnya fitrah dikatakan oleh Agustian (2002) akan membantu meningkatkan kecerdasan spiritual karena semua langkah dan pemikiran yang diambil adalah bersifat fitrah.

Inovasi yang dilakukan melalui pembelajaran berbasis masalah atau problem solving merupakan upaya membiasakan siswa untuk menghadapi berbagai masalah nantinya. Zohar dan Marshall (2002) menegaskan bahwa kecerdasan spiritual adalah kecerdasan untuk menghadapi dan memecahkan persoalan makna dan nilai. Jika siswa terbiasa dengan pemecahan masalah maka diharapkan mereka akan siap menghadapi berbagai masalah dalam dan darlam dunia nyata. Makna dan nilai pelajaran dari setiap permasalahan yang dihadapi akan membuat individu siswa akan semakin cerdas mengelola potensi diri yang dimiliki

Kemampuan mengenal dan memahami kita sepenuhnya melalui wahyu yang diturunkan Allah dikatakan oleh Suharsono (2005) sebagai ciri kecerdasan spiritual. Kegiatan intensif mendalami dan mengamalkan isi kandungan alqur'an adalah upaya melestarikan kemurnian alqur'an. Cerdas membaca pesan Allah melalui wahyuNya dalam Al-qur'an diupayakan oleh SDI Tompokersan Lumajang.

Zohar dan Marshal (2002) menggambarkan individu yang cerdas spiritual memiliki rasa kemanusiaan dan rasa syukur kepada sumber yang darinya ia dan semua lainnya berasal. Upaya yang dilakukan SDI Tompokersan Lumajang untuk selalu memberikan ilmu keagamaan, pesan-pesan sebagai perisai diri agar tidak terpengaruh dengan lingkungan yang buruk dan selalu berhati-hati dalam kehidupan sehari-hari merupakan upaya sekolah membantu siswa. Setiap hari siswa diingatkan untuk menyadari dariamana mereka berasal dan akan kemana nantinya sehingga mereka memiliki tujuan hidup yang jelas.

Cerdas mengelola dan mendayagunakan kualitas kehidupan spiritual seperti yang digambarkan Nafis (2006) juga menjadi tujuan semua warga sekolah baik siswa maupun guru. Apa yang dilakukan guru agama Islam dengan mengajak semua guru untuk memberikan teladan yang baik bagi para siswa adalah merupakan kecerdasan spiritual juga. Melalui keaktifan para guru untuk melakukan kegiatan keagamaan dan perilaku yang terpuji di dalam kehidupan sehariharinya, akan memberikan motivasi bagi para siswa untuk selalu bersikap dan melakukan kegiatan positif.

\section{SIMPULAN DAN SARAN}

SDI Tompokersan Lumajang melaku-kan sejumlah upaya dalam mengembangkan kecerdasan spiritual siswa. Pertama tafakur kepada Allah yang bertujuan mendorong siswa merenungi semua ciptaan Allah serta apa yang telah diberikan Allah kepadanya. Upaya kedua yang dikerahkan adalah mela-kukan ibadahibadah sunah seperti shalat dhuha berjama'ah dan mengaji bersama. Berikutnya adalah upaya ketiga 
yang dilakukan SDI Tompokersan Lumajang dengan cara membiasakan dzikir pada semua warga sekolah.

Upaya logika telah dilakukan dengan memberikan kesadaran kepada para siswa akan pentingnya dzikir. Selanjutnya adalah pembiasaan diri menjalani hidup secara spiritual dengan cara mendekatkan diri pada ilahi lewat dzikir yang dilakukan. Berbagai kegiatan fitrah yang dilakukan tersebut tentunya bertujuan agar terbentuk kecerdasan spiritual pada diri siswa. Sejumlah kegiatan dalam tema yang berbeda diharapkan dapat memberikan kesempatan kepada para siswa untuk merasakan nikmatnya menjalani kehidupan spiritual bersama dengan teman-teman lain.

Adapun hambatan yang dihadapi dalam pengembangan kecerdasan spiritual siswa adalah belum adanya fasilitas khusus berupa musholla yang luas dan permanen. Masalah lainnya adalah kondisi siswa yang masih kurang disiplin dalam menjalankan semua kegiatan dan kewajibannya.

Orang tua hendaknya menjadikan lingkungan keluarga sebagai pendidik yang pertama dan utama bagi siswa sehingga diharapkan keluarga dapat membendung pengaruh negatif yang dapat menghancurkan masa depan siswa. Guru di sekolah sebagai pendidik didalam lembaga pendidikan formal hendaknya berusaha mengembangkan kecerdasan spiritual dalam pembinaan moral siswa. Pemerintah dan masyarakat dilingkungan sekitar siswa juga perlu mengupayakan kegiatan yang dapat mengarahkan siswa kepada pembentukan sikap positif sebagai generasi pene-rus.

\section{DAFTAR PUSTAKA}

Abdullah. Mas Udik. 2005. Meledakkan IESQ dengan Langkah Takwa dan Trawakal. Jakarta. Zikrul Hakim.

Agustian, Ginanjar, Ary. 2001. Rahasia Sukses membangun kecerdasan Emosi dan Spiritual ESQ Berdasarkan 6 Rukun Imand an 5 Rukun Islam. Jakarta. Arga.

Angustian, Ginanjar, Ary.2003. Rahasia Sukses Membangkitkan ESQ Power, Sebuah Inner Journey Melalui Al-Ihsan. Jakarta. Arga.

Ahmadi, Abu. 1986. Metode Khusus Pendidikan Agama. Bandung. Amrico

Arikunto, Suharsimi. 2002. Prosedur Penelitian. Jakarta. Rineka Cipta.
Azra, Azyumardi. 1998. Esei-esei Intelektual Muslim Pendidikan Islam. Jakarta. Logos Wacana Ilmu.

Buzan, Tony. 2003. Sepuluh Cara Jadi Orang yang Cerdas Secara Spiritual. J akarta. PT. Gramedia Pustaka Utama.

Departemen Agama Republik Indonesia. 1996. Al-Qur'an dan Terjemahannya. Semarang. PT. Karya Toha Putra.

Hadi, Sutrisno. 1973. Metodologi Research Jilid I. Yogyakarta. Yayasan Penerbitan Fakultas Psikologi UGM.

Mujib. Abdul dan Mudzakir, Jusuf. 2002. Nuansa Nuansa Psikologi Islam, Jakarta. Hikmah.

Moleong, J, Lexy. 2002. Metodologi Penelitian Kualitatif. Bandung. Remaja Rosdakarya.

Murdalis. 1999. Metode Penelitian Suatu Pendekatan Proposal. Jakarta. Bumi Aksara.

Nashori, Fuad. 2003. Potensi-potensi Manusia. Segi Psikologi Islam. Yogyakarta. Pustaka Pelajar.

Nawawi, Hadari dan Martini, Mimi. 1994. Penelitian Terapan. Yogyakarta. Gajahmada University Press.

Ngermanto, Agus. 2005. Quantum Quotient, Cara Praktis Melejitkan IQ, EQ, dan SQ yang Harmonis. Bandung : Nuansa

Reza, A. Arasteh. 2002. Revolusi Spiritual. Depok : Inisiasi Press

Satiadarma, P. Monty, dan Waruwu E. Fidelis. 2003. Mendidik Kecerdasan. Jakarta. Pustaka Pelajar.

Suharsono. 2005. Melejitkan IQ, EQ, dan SQ. Jakarta. Insiani Perss.

Sukardarrumidi. 2004. Metodologi Penelitian, Petunjuk Praktis untuk Penleiti Pemula. Yogyakarta. Gajah Mada University Pres.

Sukidi. 2004. Kecerdasan Spiritual. Jakarta. PT. Gramedia Pustaka Utama.

Singarimbun, Misri dan Effendi Sofyan. 1993. Metode Penelitian Survai. Jakarta. Rineka Cipta.

Wahyuni Nafis, Muhammad. 2006. 9 Cara Cerdas Emosi dan Cerdas Spiritual. Jakarta. Hikmah

Yusuf, Syamsu. 2001. Psikologi Perkembangan Anak dan Remaja. Bandung. Rosda karya.

Zohar, Danah dan Marshal, Ian. 2002. SQ, Memanfaatkan Kecerdasan Spiritual dalam Berfikir Integralistik dan Holistik untuk Memaknai Kehidupan. Bandung. Mizan. 